\title{
Variasi temperatur pada proses squeeze casting berbahan magnesium semi solid terhadap hasil kekerasan
}

\author{
Tri Cahyo Wahyudi ${ }^{1}$, Eko Budiyanto ${ }^{2 \star}$ \\ 1,2Jurusan Teknik Mesin, Fakultas Teknik, Universitas Muhammadiyah Metro \\ Jl. Ki Hajar Dewantara 15 A Kota Metro, Lampung, Indonesia \\ ${ }^{*}$ Corresponding author: eko_budiyanto99@yahoo.com
}

\begin{abstract}
Squeeze casting is a casting in which the process uses high pressure with a die-punch mold applied to the molten metal when it is solidified. In semi-solid casting, the temperature of the pouring greatly affects the hardness of the material itself. In the research process to be carried out, the squeeze casting tool is modified in such a way by adding a heating element (coil heater) to the mold so that the casting process is carried out in the mold. With magnesium material, a pressure of $350 \mathrm{MPa}$ and temperature variations of $350^{\circ} \mathrm{C}, 400^{\circ} \mathrm{C}, 450^{\circ} \mathrm{C}$ and $500^{\circ} \mathrm{C}$ for a long pressing time of 1 minute, with a holding time of 5 minutes and 1 bar of argon gas pressure and one sample without treatment which aims to determine the value of material hardness and microstructure. Existing in the specimen so that later the results of this test can be applied according to the expected needs. The results obtained from this study show that the higher the temperature, the greater, the more melting in the sample, seen at a temperature of $500^{\circ} \mathrm{C}$ so that it increases the hardness value by $49.5 \mathrm{HRV}$, and affects the results of the microstructure compared to the initial material without processing, at SEM results show that at 1000 times enlargement, the size of the material structure changes to be more homogeneous as the temperature increases during the squeeze casting process.
\end{abstract}

Keywords: Squeeze casting, Magnesium, semi-solid, hardness.

\begin{abstract}
Abstrak
Pengecoran squeeze merupakan pengecoran yang dimana dalam proses tersebut menggunakan tekanan tinggi dengan cetakan berbentuk die-punch diberikan pada logam cair saat terjadi pemadatan. Pada pengecoran semi solid temperatur tuang sangat berpengaruh pada hasil kekerasan material itu sendiri. Pada proses penelitian yang akan dilakukan, alat squeeze casting dimodifikasi sedemikian rupa dengan penambahan elemen pemananas (coil heater) pada cetakan sehingga proses pengecoran dilakukan di dalam cetakan tersebut. Dengan material Magnesium, tekanan $350 \mathrm{MPa}$ serta variasi temperatur $350^{\circ} \mathrm{C}, 400^{\circ} \mathrm{C}, 450^{\circ} \mathrm{C}$ dan $500^{\circ} \mathrm{C}$ untuk lama waktu penekanan 1 menit, dengan holding time 5 menit serta tekanan gas argon 1 bar dan satu sampel tanpa perlakuan yang bertujuan untuk mengetahui nilai kekerasan bahan serta struktur mikro yang ada pada spesimen tersebut sehingga nantinya hasil dari pengujian ini dapat diaplikasikan sesuai kebutuhan yang diharapkan. Hasil yang diperoleh dari penelitian ini terlihat semakin tinggi temperatur, semakin besar, semakin banyak pula melting pada sampel, terlihat pada temperatur $500^{\circ} \mathrm{C}$ sehingganya meningkatkan nilai kekerasan sebesar 49,5 HRV, serta berpengaruh pada hasil struktur mikro bandingkan dengan material awal tanpa proses, pada hasil SEM memperlihatkan pada pembesaraan 1000 kali, Ukuran dari struktur material berubah menjadi lebih homogen seiring naiknya temperatur selama proses squeeze casting.

Kata kunci: Squeeze casting, Magnesium, semi-solid, kekerasan.
\end{abstract}




\section{Pendahuluan}

Pengecoran squeeze merupakan pengecoran yang dimana dalam proses tersebut menggunakan tekanan tinggi dengan cetakan berbentuk die-punch diberikan pada logam cair saat terjadi pemadatan. Pengecoran ini pertama kali diperkenalkan pada tahun 1878 di Rusia [1], berdasarkan cara pengisian logam cair ke dalam cetakan, pengecoran squeeze dikelompokkan menjadi dua, yaitu: direct squeeze casting (DSC) dan indirect squeeze casting (ISC). Penelitian ini menggunakan proses direct squeeze casting [2]. Semi solid merupakan bahan yang diproses dalam kondisi antara fasa cair dan padat dan metode pengerjaannya menggunakan metode pengecoran atau pembentukan, sifat magnesium yang ringan dan juga memiliki kekuatan yang relatif baik memiliki potensi besar pada industri dalam hal proses semi solid [3].

Pada pengecoran semi solid temperatur tuang sangat berpengaruh pada hasil struktur mikro serta hasil kekerasan pada material tersebut [4]. Dimana hasil pengujian menunjukkan bahwa semakin tinggi tekanan yang diberikan pada benda uji maka nilai kekerasan semakin meningkat [5]. Begitupun juga seiring dengan kenaikan temperature cetakan [6].

Dalam proses pengujian sifat mekanik pengujian kekerasan adalah salah satu pengujian yang dapat dilakukan untuk mengetahui nilai atau hasil suatu material yang telah di lakukan proses pengecoran semi solid. Hasil struktur mikro memperlihatkan nilai kekerasan material meningkat seiring kenaikan temperatur cetakan [7]. Dimana kekerasan pada permukaan tekan dipengaruhi oleh temperatur, penuangan, tekanan, waktu dan gaya penekanan [8].

Pada proses penelitian yang akan dilakukan, alat squeeze casting dimodifikasi sedemikian rupa dengan penambahan elemen pemananas (coil heater) pada cetakan sehingga proses pengecoran dilakukan di dalam cetakan tersebut, dengan memberikan variasi temperatur, yang bertujuan untuk mengetahui nilai kekerasan bahan serta struktur mikro yang ada pada spesimen tersebut sehingga nantinya hasil dari pengujian ini dapat diaplikasikan sesuai kebutuhan yang diharapkan.

\section{Tinjauan Pustaka}

\section{Semi Solid Casting}

Semi solid merupakan suatu proses pengecoran diaman bahan yang diproses dalam kondisi fasa antara cair dan padat (semisolid atau semi liquid), serta metode pengerjaannya menggunakan metode pengecoran atau pembentukan diperoleh dengan cara memanaskannya di atas temperatur solid. Kelebihan proses ini yaitu kompleksitas bentuk produk dan kecepatan produksi yang relatif tinggi seperti halnya proses die casting, cacat porositas dan segregasi makro yang relatif rendah sehingga kekuatan dan keuletannya relatif tinggi, pada saat dipanaskan di atas temperatur solid, bahan baku terdiri atas fasa padat berbentuk globular (spheroidal) dan fasa cair yang berada di antara fasa padat, dengan istilah fase dendrit, dan logam yang berfasa cair berada diantara dendrit atau lengan dendrit. Selanjutnya, fasa cair bertransformasi menjadi fasa eutektik ketika pendinginan mencapai temperatur solidus atau eutektik. Secara umum, struktur dendrit ini merupakan ciri produk proses pengecoran logam.

Pada temperatur proses yang lebih rendah menyebabkan gas hidrogen yang terlarut ke bahan baku menjadi lebih rendah sehingga dengan proses semisolid forming cacat porositas yang disebabkan gas hidrogen dapat dikurangi. Temperatur pemanasan yang terlalu tinggi menghasilkan viskositas logam semisolid yang terlalu rendah viskositasnya, oleh karena itu pada proses semisolid [9]. menjelaskan salah satu alasan untuk berbagai penelitian dan pengembangan SSM (semi solid metal) untuk Aluminium dan Magnesium mungkin merupakan perbedaan metalurgi mendasar dari Aluminium dan paduan Magnesium casting. 


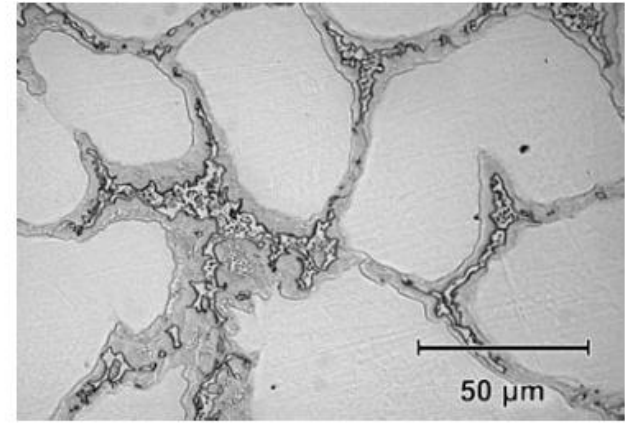

Gambar 1. Struktur mikro SSM yang diproses AZ91 menunjukkan eutektik nonekuilibrium antara partikel Al-Mg [9].

Diagram fase biner pada gambar 2 adalah dasar untuk memperkirakan kesesuaian paduan yang berbeda untuk pemrosesan SSM. Fraksi cair yang memadai adalah syarat dalam pengolahan SSM.

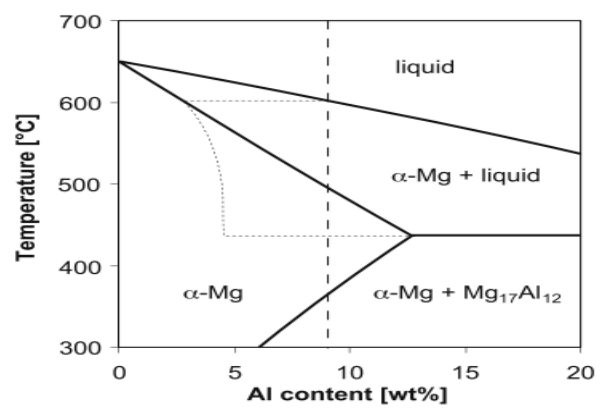

Gambar 2. Diagram fase biner $\mathrm{Mg}-\mathrm{Al}$, garis putus-putus mewakili solidifikasi nonekuilibrium paduan $\mathrm{Mg}-9 \% \mathrm{Al}$ [9].

\section{Squezze Casting}

Merupakan proses pengecoran, dimana logam cair dituang dan diberikan tekanan sampai proses pemadatan selesai dengan mengunakan tekanan hidrolik, teknik ini mampu meningkatkan sifat fisis dan mekanis terutama pada material paduan dasar alumunium dan magnesium [10]. Perlakuan tekanan yang diberikan akan kontak langsung terhadap logam cair dengan dinding cetakan serta menyebabkan perpindahan panas yang akan memperngaruhi kepadatan stuktur mikro logam tersebut, alat squeeze casting ditunjukkan pada Gambar 3.

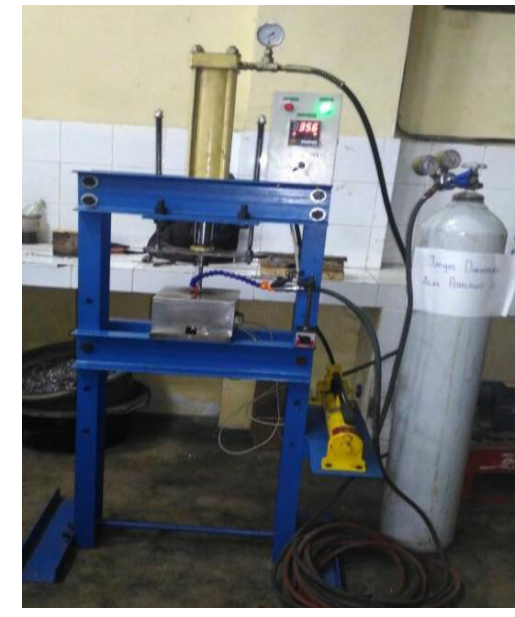

Gambar 3. Alat squeeze casting.

Pada penelitian [8] menggunakan teknik direct squeeze casting dengan cara material Almunium cair dituang ke dalam dies/cetakan kemudian ditekan. Proses ini mampu menghasilkan kekerasan permukaan dengan presentase sampai $22 \%$, dimana kekerasan permukaan tekan dipengaruhi oleh suhu penuangan, tekanan waktu dan gaya penekan.

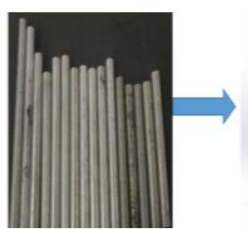

Material awal

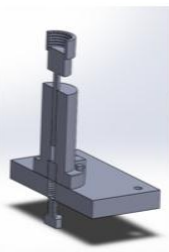

Proses

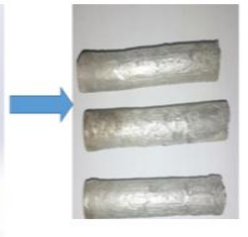

Hasil dari proses
Gambar 4. Alur pembuatan squeeze casting.

Pada Gambar 4 merupakan alur pembuatan material squeeze casting, dimana material awal ketika sudah berbentuk silinder dimasukkan ke dalam dies lalu di-squeeze, selama proses tersebut material dalam kondisi semi solid, setelah proses selesai barulah material dikeluarkan dari dies.

\section{Direct Squeeze Casting (DSC)}

Direct squeeze casting merupakan sebuah proses bisa dikatakan sebuah proses liquid metal forging, squeeze forming, extrusion casting dan pressure crystallisation, (DSC) adalah proses dimana logam cair didinginkan dengan memberikan tekanan secara langsung yang bertujuan untuk mencegah terjadinya porositas gas serta 
penyusutan pada sebuah material. Seperti yang diperlihatkan pada Gambar 5.

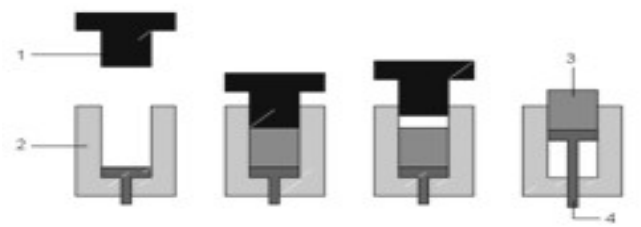

Gambar 5. Mekanisme (DSC) Direct Squeeze Casting.

Proses Direct Squeeze Casting (DSC) mempunyai keuntungan yaitu memperkecil terjadinya porositas gas dan penyusutan, menghilangkan gating system, sehingga tidak terjadi pembuangan material. Sifat mekanik hasil pengecoran menggunakan komposisi yang sama dapat menghasilkan coran yang baik bahkan lebih baik bila dibandingkan dengan produk coran teknik yang lain melalui perilaku isotropik, untuk itu faktor pengecoran dianggap satu kesatuan.

Sifat lelah pada squeeze cast magnesium alloy secara signifikan dapat ditingkatkan dibandingkan bahan yang lain dengan metode yang sama, pada proses melalui squeeze cast dapat membuat bentuk yang rumit serta menghemat biaya pembuatan [11]. Pada proses pengecoran squeeze menghasilkan produk akhir dengan kualitas yang baik. Hasil dari proses cor dilihat dengan struktur mikro lebih dan homogen serta memiliki sifat mekanik yang baik.

\section{Pengujian Microhardness}

Pengujian kekerasan adalah satu dari sekian banyak pengujian yang dipakai, karena dapat dilaksanakan pada benda uji yang kecil tanpa kesukaran mengenai spesifikasi, pengujian kekerasan merupakan cara yang paling umum digunakan karena beberapa alasan yaitu, tidak bersifat merusak memiliki keuntungan dan kemudahan mengkonversika nnkekerasan dengan perhitungan menggunakan skala, pengujian yang paling banyak dipakai adalah dengan menekankan penekan tertentu kepada benda uji dengan beban tertentu dan dengan mengukur ukuran bekas penekanan yang terbentuk di atasnya.

\section{Pengujian Metalografi.}

Metalografi merupakan disiplin ilmu yang mempalajari karakteristik mikrostruktur dan makrostruktur suatu logam, paduan logam dan material lainnya serta hubungannya dengan sifat-sifat material atau biasa juga dikatakan suatu proses mengukur suatu material bahan secara kualitatif maupun kuantitatif berdasarkan informasi-informasi yang didapatkan dari material yang diamati, dalam ilmu metalurgi struktur mikro merupakan hal yang sangat penting untuk dipelajari karena struktur mikro sangat berpengaruh pada sifat-sifat mekanik suatu logam. Struktur mikro yang kecil akan membuat kekerasan logam meningkat dan juga sebaiknya, struktur mikro yang besar akan membuat logam menjadi ulet atau kekerasannya menurun, struktur mikro itu sendiri dipengaruhi oleh komposisi kimia dari logam tersebut, metalografi bertujuan mendapatkan struktur makro dan mikro dari suatu logam sehingga dapat dianalisa sifat mekanik dari suatu logam tersebut.

Menurut penelitian [12] pada Gambar 6 yaitu struktur mikro dari spesimen AZ31 didinginkan dengan berbagai suhu setelah menahan isotermal selama 1800 detik pada gambar (a).

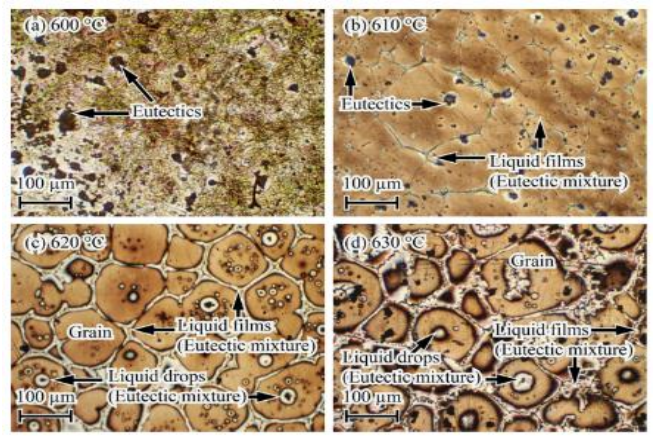

Gambar 6. Struktur mikro Dari spesimen AZ31 didinginkan dengan berbagai suhu setelah menahan isotermal selama 1800 detik.

Untuk mengamati struktur mikro yang terbentuk pada logam yang diamati biasanya memakai mikroskop optik, sebelum benda uji diamati dengan mikroskop optik, benda uji terebut harus melewati tahap-tahap preparasi, tujuannya agar pada saat mengamati benda yang diuji, struktur mikronya terlihat dengan 
jelas, semakin sempurna preparasi benda yang akan diuji, semakin sempurna gambar yang akan diperoleh, pada skala pengamatan mikro yaitu pengamatan 100 kali atau lebih besar yang diamati pada fasa, besar butir dan endapan, pada metalografi yang diperoleh dengan suatu analisa kimia dan metalografi logam atau paduannya dan potongannya disebabkan oleh logam tersebut. Pembawaan ketidak homogenan dalam suatu logam lebih ditentukan dengan macroetching dan pemasarannya dapat dilakukan dengan menggunakan luas power mikropis, ini dinotasikan olah jenis metalografi data yang diperlukan atau dibutuhkan.

\section{Metode Penelitian}

Alur Penelitian dapat dijelaskan sebagai berikut:

1. Menyiapkan material atau bahan yang akan di lakukan proses squeeze casting, dimana material tersebut sudah di bubut sesuai dimensi cetakan.

2. Menyalakan stop kontak untuk memanaskan cetakan atau dies.

3. Memasang ejector pada lobang cetakan di bagian bawah lalu kencangkan menggunakan baut.

4. Mengatur temperatur cetakan sesuai yang diperlukan.

5. Ketika temperatur sudah sesuai, memasukan spesimen ke dalam cetakan lalu mengencangkan punch.

6. Selama proses tersebut gas argon diarahkan ke bagian cetakan disertakan mengatur holding time, lama holding time disesuaikan dari penelitian.

7. Ketika semua proses sudah dilakukan kemudian ditekan, setelah itu dibuka baut ejector nya untuk menarik ejector, kemudian material dikeluarkan.

8. Lakukan proses berulang ulang tersebut sampai sesuai keutuhan.

9. Melakukan uji kekekerasan.

10. Melakukan uji struktur mikro.

\section{Hasil dan Pembahasan}

\section{Hasil Uji Mikrohardness}

Di dalam peoses penelitian untuk pengujian mikrohardnes, material yang digunakan terdiri dari material yang sudah di lakukan proses squeeze casting dengan tekanan $350 \mathrm{MPa}$ serta variasi temperatur $350^{\circ} \mathrm{C}, 400^{\circ} \mathrm{C}, 450^{\circ} \mathrm{C}$ dan $500^{\circ} \mathrm{C}$ untuk lama waktu penekanan 1 menit, dengan holding time 5 menit serta tekanan gas argon 1 bar dan satu sampel tanpa perlakuaan diuji untuk membandingkan hasil dari material yang sudah dilakukan proses squeeze casting yang berfungsi untuk mengetahui seberapa besar pengaruh dari temperatur terhadap hasil kekerasan material yang sudah dilakukan proses tersebut. Adapun data setelah pengujian terdapat pada tabel dan grafik Gambar 7.

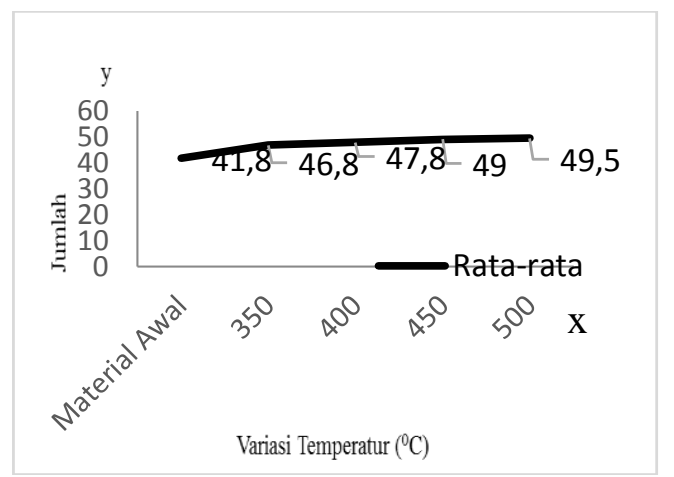

Gambar 7. Grafik hasil uji mikrohardness tekanan $350 \mathrm{MPa}$ variasi temperatur.

Hasil uji variasi tempertur maupun tanpa perlakuan di perlihatkan pada gambar grafik 7 di atas, nilai rata-rata pada uji mikrohadness tidak terlalu jauh pada temperatur $350^{\circ} \mathrm{C}$ nilai kekerasanya 46,8 HRV nilai tersebut kemudian naik pada temperatur $400^{\circ} \mathrm{C}$ dengan nilai $47,8 \mathrm{HRV}$ selanjutnya di temperatur $450^{\circ} \mathrm{C}$ nilai ratarata kekerasanya 49 , dan puncak dari nilai kekerasan berada pada temparatur $500^{\circ} \mathrm{C}$ dengan nilai 49,5 HRV dari keempat variasi temperatur tersebut menujukan nilai kekerasan cukup baik di bandingkan pada sampel yang tanpa perlakuan yaitu sebesar 41,8 HRV.

Pada temperatur $350^{\circ} \mathrm{C}$, merupakan temperatur rendah, serta nilai kekerasannya 
belum begitu terlihat naik secara signifikan, berbeda dengan temperatur $400^{\circ} \mathrm{C}, 450^{\circ} \mathrm{C}$ nilai kekerasanyapun naik dan mencapai puncaknya pada temperatur $500^{\circ} \mathrm{C}$, hal ini disebabkan mungkin pada suhu tersebut perubahan dari struktur material mulai terlihat, sehingga dalam hubungan antara temperatur dengan kekerasan terlihat bahwa semakin besar temperatur yang diberikan pada saat squeeze casting maka semakin tinggi pula nilai dari kekrasan materialnya.

\section{Hasil Pengujian Struktur Mikro}

Struktur mikro adalah gambaran dari kumpulan fasa-fasa yang dapat diamati melalui teknik metalografi, struktur mikro suatu logam dapat dilihat dengan menggunakan mikroskro, pengujian struktur mikro yang menggunakan micro hardenes tester dengan pembesaran $100 \mu \mathrm{m}$ dan 500 $\mu \mathrm{m}$. Hasil pengujian yang telah dilakukan dari hasil pengujian sampel dari squeeze casting magnesium AZ31 dengan variasi temperatur dengan tekanan, adapun sampel yang tanpa perlakuan dilakukan pengujian struktur mikro, hal ini dilakukan untuk mengetahui dan membandingkan struktur mikro yang dilakukan variasi, apakah hasil tersebut mempunyai kesamaan atau ada unsur yang lain, hasil pengujian dapat dilihat pada Gambar 8.

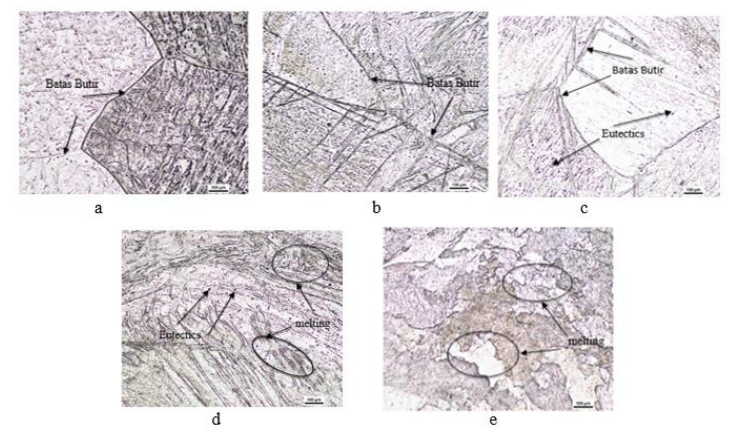

Gambar 8. Struktur mikro tekanan 350 MPa dengan variasi temperatur.

Pada pengujian metalografi struktur mikro material awal pada gambar 8a tidak mengalami perlakuan panas dan terlihat masih berupa batas butir dan masih dalam keadaan solid, berbeda sedikit pada temperatur $350^{\circ} \mathrm{C}$ gambar $8 \mathrm{~b}$ masih terlihat batas butir nya walaupun tidak terlalu jelas, kemudian pada struktur mikro temperatur $400^{\circ} \mathrm{C}$ pada Gambar 8c, terlihat lebih rapi dan halus berbeda dengan sampel yang sebelumnya, serta terdapat titik-titik eutectics. Perbedaan bentuk butiran disebabkan karena sampel telah menerima perlakuan panas yang memperbaiki bentuk butiranya tersebut, titik - titik eutectics pada foto tersebut terlihat sedikit berkurang serta unsur-unsur lainnya sudah tercampur dengan Magnesium seiring bertambahnya temperatur, dan lebih cendrung banyaknya cairan putih yang asumsikan unsur Magnesium serta masih ada juga batas butirnya walaupun tidak terlihat jelas. Berbeda dengan temperatur sebelumnya, pada gambar $8 \mathrm{~d}$ temperatur $450^{\circ} \mathrm{C}$ juga dimana pada temperatur ini struktur mikro sudah mulai berubah bentuk, perubahan tersebut disebabkan hubungan temperatur yang semakin naik, terlihat bahwa ada beberapa tempat yang sudah mengalami fase remelting dimana perubahan tersebut terjadi pada batas butir, walaupun demikian unsur yang tercampur belum seutuhnya, perubahan unsur sangat terlihat jelas pada gammbar $8 \mathrm{e}$ temperatur $500^{\circ} \mathrm{C}$ dimana peleburan lebih lanjut meningkat sehingga mengakibatkan struktur mikronya terlihat lebih membesar serta lebih kasar, pada temperatur tersebut sampel uji menjadi berubah bentuk seperti meleleh tetapi tidak mencair atau remelting, titik melting ini lebih banyak terjadi di setiap bagian, ini membuktikan bahwa melting terjadi tidak hanya pada batas butir tapi juga di dalam batas butir saat spesimen dipanaskan, sehingga mengahsilkan nilai kekerasan yang tinggi. Proses temperatur dapat mempengaruhi bentuk struktur mikro dari setiap variasi temperaturnya dan sangat berbeda jika dibandingkan dengan kondisi awal tanpa proses pemanasan.

\section{Hasil Uji Scanning Electron Microscope (SEM)}

Uji metalurgrafi dilakukan untuk menganalisa permukaan dengan skala pembesaran yang ditentukan. Pada penelitian ini pengujian metalografi 
menggunakan Scanning electron microscope (SEM) hasil pengujian SEM dapat dilihat pada Gambar 9.

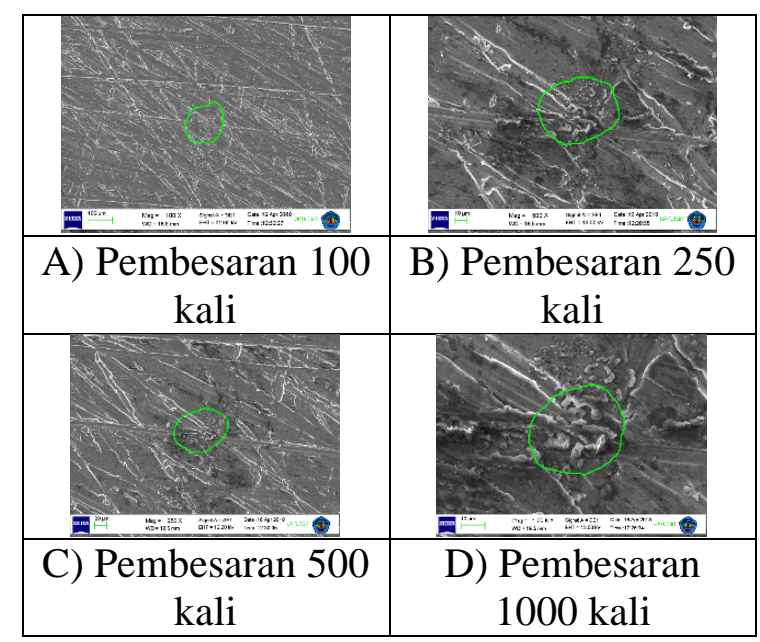

Gambar 9. Hasil SEM material tekanan $350 \mathrm{MPa}$ dengan temperatur $500^{\circ} \mathrm{C}$.

Berdasarkan hasil pengujian menggunakan SEM memperlihatkan hasil bahwa pengecoran squeeze casting pada tekanan $350 \mathrm{MPa}$ pada temperatur $500^{\circ} \mathrm{C}$, pada gambar 9A dengan pembesaran 100 kali belum nampak butiran-butiran namum terlihat jelas hanya seperti goresan begitupun pada gambar 9B dengan pembesaran 250 kali, namun pada pembesaran 500 kali yang terlihat pada gambar 9C terlihat perbedaan pada permukaan, dimana terlihat perubahan bentuk, itu terjadi karena selama proses tersebut material sudah berada dalam kondisi mendekati melting, sehingga butiran pada permukaan terlihat berbeda dari pada permukaan di sekitarnya. Nampak jelas hasil permukaan terlihat pada gambar 9D pada pembesaraan 1000 kali, ukuran dari struktur material berubah menjadi lebih homogen seiring naiknya temperatur selama proses squeeze casting.

Penerapan tekanan $350 \mathrm{MPa}$ pada perlakuan temperatur $500^{\circ} \mathrm{C}$ yang diberikan secara langsung menyebabkan berpengaruh terhadap kepadatan struktur mikro, sehingga mempengaruhi kekerasan permukaan pada material tersebut. Fenomena ini jelas sekali bahwa dengan meningkatnya temperatur berpengaruh pada hasil serta perubahan struktur ini disebabkan semakin tinggi temperatur cetakan maka perbedaan dengan temperatur logam semakin rendah yang mengakibatkan laju pembekuan yang semakin lambat.

\section{Kesimpulan}

Dalam penelitian ini dapat disimpulkan bahwa temperatur sangat mempengaruhi hasil dari struktur mikro pada pengujian ini terlihat semakin tinggi temperatur, semakin besar, semakin banyak pula melting pada sampel, hal ini terlihat terlihat pada temperatur 5000C sehingganya meningkatkan nilai kekerasan, nilai kekerasan pada variasi temperatur berada pada 5000C sebesar 49,5 HRV. Proses temperatur dapat mempengaruhi bentuk struktur mikro dari setiap variasi temperaturnya dan sangat berbeda jika di bandingkan dengan kondisi awal tanpa proses pemanasan. Berdasarkan hasil pengujian menggunakan SEM memperlihatkan hasil pada pembesaraan 1000 kali. Ukuran dari struktur material berubah menjadi lebih homogen seiring naiknya temperatur selama proses squeeze casting.

\section{Referensi}

[1] Soejono Tjitro dan Firdaus., 2002. Pengecoran Squeeze. Fakultas Teknologi Industri. Universitas Kristen Petra. Surabaya.

[2] T.M, Yue. and G.A. Chadwick., 1996. squeeze casting of light alloys and their composites. Journal of Material Processing Technology, Vol. 58 No. 2 $-3$.

[3] H.R, Abedi, al., 2010. The semi-solid tensile deformation behavior of wrought AZ31 magnesium alloy. Materials and Design 31, 4386-4391.

[4] M, Chambali, dkk., 2013. Pengaruh Temperatur Bahan Terhadap Struktur Mikro Dan Kekerasan Pada Proses Semi Solid Casting Paduan Alumunium Daur Ulang.Vol. 9, No. 1, Hal 6-12. 
[5] Muhammad Syaiful Nurkholiq, dkk., 2013. Analisa Pengaruh Variasi Tekanan Dan Pada Pengecoran Squeeze Terhadap Kekerasan Produk Sepatu Kampas Rem Dengan Bahan Alumunium (Al) Silicon (Si) Daur Ulang. Universitas Wahid Hasyim.

[6] Nur Wakhid., 2018. Rancang bangun perangkat squeeze casting untuk pembuatab bahan dasar material baut tulang berbasis magnesium AZ31. Universitas lampung. Lampung.

[7] Eddy, Djatmiko, Dan Budianto., 2011. Analisis Sifat Mekanis Dan Struktur mikro Pada Produk Paduan Al78Si22 Metode Squeezing Casting. Universitas pancasila. Prosiding Seminar Nasional Pengembangan Energi Nuklir IV, 2011.

[8] Taufikurrahman. et al., 2013. Effect Of The Squeeze Process On The Hardhess And Micro Stucture Of Recyled Alumunium Materials. Journal Of Mechanical Science And Engineering. Vol.1 no.1 October.

[9] Horst, E, Friedrich, Mordike, B. L. 2006. Magnesium Technology Metallurgy, Design Data, Applications. Germany. $665 \mathrm{hlm}$.

[10] Zhi-hong GUO, et al., 2012. Optimiz ation of AZ80 Magnesium Alloy Squeeze Cast Process Paramete rs Using Morphological Matrix. Tran s.nonferrous Met. Soc. China. 22.411418.

[11] M, Horynová, rt al., 2013. Evaluation of fatigue life of AZ31 magnesium alloy fabricated by squeeze casting. Material and Design. 45. 253-264.

[12] Y, Men, Fukushima, et al., 2015. Cold Formability Of AZ31 Wrought Magnesium Alloy Undergoing SemisolidSpheroidization Treatment, Materials Science \& Engineering A 624 148-156. 